\title{
PReS-FINAL-2079: Will cooling an arthritic joint cause damage? - an analysis of different cooling methods in patients with jia using thermography
}

\author{
M König ${ }^{1 *}$, F Kreuzpointner ${ }^{1,2}$, M Hartmann ${ }^{1}$, M Georgi ${ }^{1}$, HJ Händel ${ }^{1}$, A Schwirtz ${ }^{2}$, JP Haas $^{1}$ \\ From 20th Pediatric Rheumatology European Society (PReS) Congress \\ Ljubljana, Slovenia. 25-29 September 2013
}

\begin{abstract}
Introduction
Physical therapy is one part of the multidisciplinary treatment in patients with juvenile idiopathic arthritis (JIA) (Spamer 2012). Usually joints with acute arthritis are treated with ice but apart from the analgetic effects the precise effects remain unknown. Local cooling may decrease the inflammatory reaction (Swenson, Sward et al. 1996) but there exist no systematic data about the optimal temperature and method of cooling. The temperature suitable to induce a benefit without causing harm has not been determined yet.
\end{abstract}

\section{Objectives}

This study compares two different cooling methods according the surface temperature induced in an arthritic knee joint within a routine application.

\section{Methods}

Nine JIA patients (age $13.1 \pm 2.5$ yrs) with unilateral gonarthritis had been included in a crossover design. Both methods were compared with two subsequent days of treatment. The healthy knee joint served as a control group. The cooling period was 12 minutes. Method A: cooling the joint with a classical kryo-pack with an initial temperature of about $5^{\circ} \mathrm{C}$. Method B: was a cuff purged with water with constant temperature of $17^{\circ} \mathrm{C}$ allocated by a cooling system (Hilotherm Clinic, Hilotherm GmbH, Argenbuehl-Eisenharz, Germany). The observation period of the surface temperature around the patella was $20 \mathrm{~min}$ utes after cooling. Furthermore the linear fit of the rewarming curve (minimum temperature) after application has been calculated to examine the slope in terms of

Deutsches Zentrum für Kinder- und Jugendrheumatologie GarmischPartenkirchen, Garmisch-Partenkirchen, Germany

Full list of author information is available at the end of the article hyperemia - the steeper the fit, the higher the risk of hyperemia.

\section{Results}

The initial mean temperature after cooling was $23.7 \pm 3.2^{\circ}$ $\mathrm{C}(\operatorname{method} \mathrm{A})$ and $29.1 \pm 2.1^{\circ} \mathrm{C}(\operatorname{method} \mathrm{B})(\mathrm{p}<.05)$. Twenty minutes after cooling skin temperature was $31.3 \pm$ $3.1^{\circ} \mathrm{C}(\mathrm{A})$ and $31.9 \pm 1.6^{\circ} \mathrm{C}(\mathrm{B})(\mathrm{p}>.05)$. Compared to the control group (method A: $33.4 \pm 1.8^{\circ} \mathrm{C}$, method B: $33.1 \pm$ $1.1^{\circ} \mathrm{C}$ ) both methods produced significant lower values for the skin temperature after 12 minutes of cooling. The slope of both fits were statistical significant different (method A: $11.7 \pm 5.2^{\circ}$, method B: $23.0 \pm 5.0^{\circ} ; \mathrm{p}<.01$ ).

\section{Conclusion}

Both methods reached a lower temperature after 12 minutes of cooling with respect to the control joint. They have proofed to have a similar effect according temperature and duration. But the main difference between both methods was that method $\mathrm{B}\left(29.1 \pm 2.1^{\circ} \mathrm{C}\right)$ has a statistically significant higher temperature after a cooling period of 12 minutes than method $\mathrm{A}\left(23.7 \pm 3.2^{\circ} \mathrm{C}\right)$ which might be more compatible. This could prevent from possible soft tissue damage.

The slope of the rewarming curve may serve as indicator for a faster rewarming effect which might cause hyperemia.

\section{Disclosure of interest}

None declared.

\section{Authors' details}

${ }^{1}$ Deutsches Zentrum für Kinder- und Jugendrheumatologie GarmischPartenkirchen, Garmisch-Partenkirchen, Germany. ${ }^{2}$ Department for Biomechanics in Sport, Technische Universität München, München, Germany. 

arthritic joint cause damage? - an analysis of different cooling methods in patients with jia using thermography. Pediatric Rheumatology 2013 11(Suppl 2):P91.

Submit your next manuscript to BioMed Central and take full advantage of:

- Convenient online submission

- Thorough peer review

- No space constraints or color figure charges

- Immediate publication on acceptance

- Inclusion in PubMed, CAS, Scopus and Google Scholar

- Research which is freely available for redistribution

Submit your manuscript at www.biomedcentral.com/submit
C Biomed Central 